Article

\title{
Energy and Economic Efficiency of Maize Agroecosystem under Three Management Strategies in the Frailesca, Chiapas (Mexico)
}

\author{
Franklin B. Martínez ${ }^{1}{ }^{\mathbb{D}}$, Francisco Guevara ${ }^{2, * \mathbb{D}}$, Carlos E. Aguilar ${ }^{2}$, René Pinto ${ }^{2}$, \\ Manuel A. La O ${ }^{2}$, Luis A. Rodríguez ${ }^{3}$ and Deb R. Aryal ${ }^{4}$ \\ 1 Estudiante de Doctorado en Ciencias Agropecuarias y Sustentabilidad, Universidad Autónoma de \\ Chiapas (UNACH), Carretera Ocozocoautla-Villaflores Km. 84.5, Villaflores C.P. 30470, Mexico; \\ franklinmar7820@yahoo.com.mx \\ 2 Investigador de la Universidad Autónoma de Chiapas (UNACH), Facultad de Ciencias Agronómicas. \\ Carretera Ocozocoautla-Villaflores Km. 84.5, Villaflores C.P. 30470, Mexico; \\ ceaj2001@yahoo.com.mx (C.E.A.); pinto_ruiz@yahoo.com.mx (R.P.); pacholaoarias@gmail.com (M.A.L.O) \\ 3 Investigador de Facultad de Ingeniería, Sede Villa Corzo. Universidad de Ciencias y Artes de \\ Chiapas (UNICACH), Carretera Villa Corzo-Monterrey Km 3, Villa Corzo C.P. 30520, Mexico; \\ luislarra2012@gmail.com \\ 4 Facultad de Ciencias Agronómicas, CONACYT-UNACH, Villaflores C.P. 30470, Mexico; \\ debraj.aryal@hotmail.com \\ * Correspondence: francisco.guevara@unach.mx
}

Received: 4 February 2020; Accepted: 10 March 2020; Published: 15 March 2020

\begin{abstract}
Analysis of energy flows and economic dynamics allows the diversity of variables involved in the agroecosystem production to be observed in the same dimension. In this way, efficiency and performance can be analysed integrally to identify critical points to be improved. The objective of this study was to analyse the energy-economic efficiency within three management strategies (Management I, Management II and Management III) of the maize agroecosystem in the Frailesca region of Chiapas (Mexico). The hypothesis was that systemic typologies, defined by modes of production, can lead to different efficiencies for the system performance. The study was descriptive; case studies were selected as representative based on their technological variants. The efficiency analysis was conducted using a balance of inputs and outputs expressed in energy and economic terms. Management III resulted in better energy use efficiency, with 6.47, while Management I and Management II were more economically feasible, with a benefit/cost ratio of 1.56 pesos.
\end{abstract}

Keywords: maize agroecosystem; energy balance; economic feasibility

\section{Introduction}

Maize is one of the most important cereals for human sustenance [1], and its use has extended to animal feeding and obtaining biofuel [2,3], resulting in demand for higher production. In Mexico, production has increased 75\% from 1980 to 2016, while the area cultivated under maize has increased only 3\% [4]. This increase is the consequence of genetic improvement of the species and of technology based on synthetic fertilizers and other agrochemicals and machinery, which have resulted in higher yield per unit of area.

In Mexico, maize is cultivated commercially and for home consumption by small farmers and their families, who use different types of management for maize production $[5,6]$. Previous researches in Frailesca (Chiapas) found, from a technological point of view, a diversity of management strategies for the maize agroecosystem, and two productive visions were identified. On the one hand, there is a 
conventional vision based on the use of a "technological packages" approach towards agroecosystem intensification, which completely depends on industrial inputs such as the agrochemicals, machines and commercial seeds. The aiming is the economic efficiency of the agroecosystem. On the other hand, there is an environmental vision based on agroecological approaches and promotes the minimum use of industrial inputs, recognises and uses local technologies and seeks for the efficiency of the agroecosystem. However, there are in-between perspectives where characteristics of both visions come together dynamically. Authors like Ocaña [6] and Guevara et al. [7] conducted some studies on those technological aspects observed in both visions as well as in the in-between perspectives.

This background settled up a scenario for the current study, taking into consideration the findings regarding three management strategies for maize production in the region. Management I, with permanent requirements of energy from fossil sources in all its production stages. Such energy supports the agricultural components such as agrochemicals, machinery and water pumps for irrigation, as well as for cultivation practices and harvest [8-10]. On the other side, Management II is associated to agroecological practices and is characterised by greater dependence on labour, leading to reduced industrial energy, incorporation of practices for soil conservation, intercropping and use of residues from harvest. It is closer to a kind of traditional agriculture. In-between there is Management III, combining elements from Management I and II, which uses some industrial energy, integrates soil conservation practices and uses commercial seed varieties into the agroecosystem, among other shared elements.

In the Frailesca, $88 \%$ of the growers use fertilizers and $76 \%$ use insecticides and herbicides, representing a strong industrial energy component [7]. Moreover, $92 \%$ of the growers use improved seed, while $8 \%$ prefer local seed [11,12]. These high industrial energy expenditures, as part of the energy input in the production process, are closely related to greenhouse gas emissions (GGE) [13,14]. This situation means that there has been a substitution of intangible process technologies with a strong component of information and knowledge by technologies of inputs associated with industrial development and, therefore, with higher economic costs [15-17].

For the above reasons, in the methodological context of systemic-energy analyses of agroecosystems, two basic sources of energy are identified: ecological and cultural. The first comes directly from the sun, while the second is attributed to all anthropic activity through agricultural technologies. In turn, this cultural energy can have a biological origin (human work, animal work and organic materials) or industrial (fossil energy, agrochemicals and machinery) [18,19].

In this sense, it is necessary to measure the energy flow in the system for production of a good to determine the expenditure of energy and improve its efficiency [20] and, in this way, obtain a product that is economically profitable and has less negative impact on the environment [21]. In this sense, energy use efficiency would explain the dynamics of energy within an agroecosystem, ranch or farm, by means of a balance between the energy invested, or energy inputs, and the energy produced, or energy outputs [22,23]. To this end, the objective of this study was to conduct a comparative analysis on the energy-economic efficiency of the maize agroecosystem under three management modes (Management I, Management II and Management III) in the Frailesca (Chiapas), under the hypothesis that systemic typologies, defined by the type of management, will lead to different performance of efficiency indicators assessed from a systemic perspective.

\section{Materials and Methods}

\subsection{Location of the Study Area}

The study was conducted in the Frailesca region of the state of Chiapas, which is located on the Central Depression of the State, comprising the following municipalities: Villaflores, Villa Corzo, La Concordia, Angel Albino Corzo, Montecristo de Guerrero and El Parral (Figure 1). It is characterised by its important agricultural activity, especially by its area for maize production. The region's climates are in the groups of warm and semi-warm. Warm sub-humid climate with summer rains predominates, 
followed by semi-warm humid with abundant summer rain. From May to October, average minimum temperatures oscillate between $12{ }^{\circ} \mathrm{C}$ and $21^{\circ} \mathrm{C}$. Rainfall during these months oscillates between $1000 \mathrm{~mm}$ and $2600 \mathrm{~mm}$. In the period from November to April, the average minimum temperatures vary from $9{ }^{\circ} \mathrm{C}$ to $15^{\circ} \mathrm{C}$, with averages of $12{ }^{\circ} \mathrm{C}$ to $15^{\circ} \mathrm{C}$ in $92.96 \%$ of the region. During this period, rainfall is $25 \mathrm{~mm}$ to $30 \mathrm{~mm}$ [24].

The Frailesca is characterised by small farmers with plots for maize production up to 6 hectares. Maize is cropped in annual cycles and is based on the rainy season, which is defined from June to December. Traditional tillage techniques are employed by using local tools like the coa (planting stick), hoe, machete and simple equipment such as sprinklers for the application of chemical products. During the harvest season, corn small shelling machines are used too. The average maize yield for the Frailesca is $3.5 \mathrm{tha}^{-1}$ and for the state of Chiapas the average maize yield is $1.9 \mathrm{t} \mathrm{ha}^{-1}$.

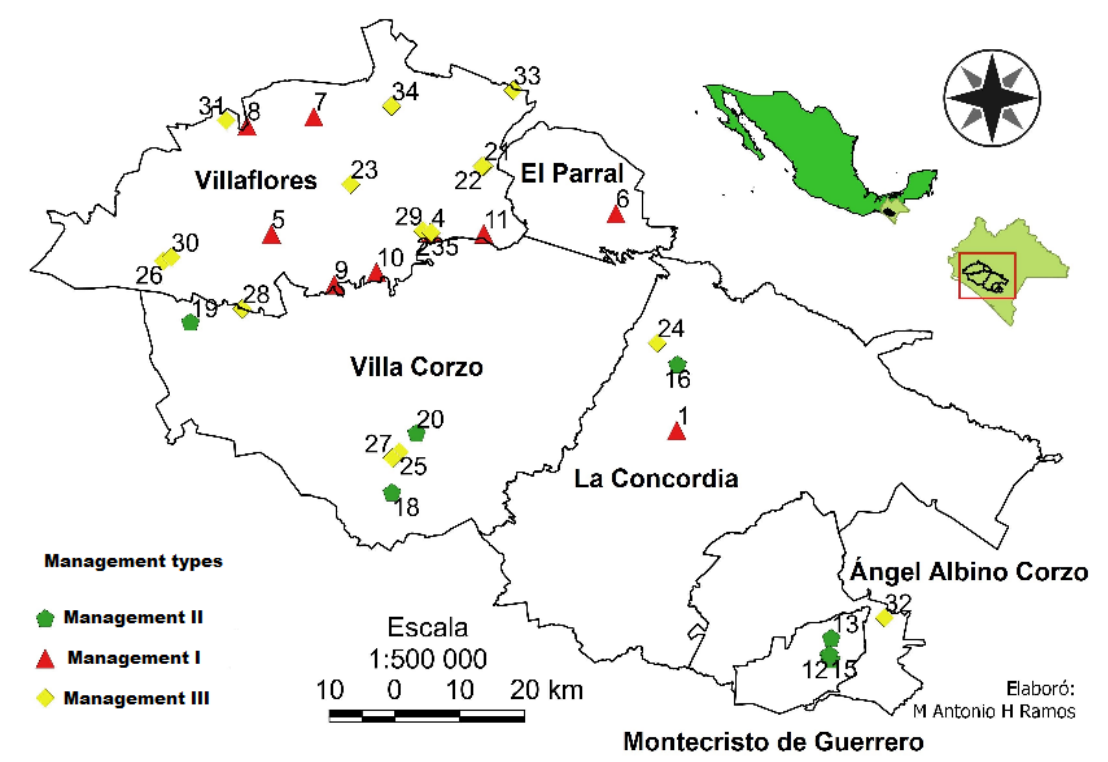

Figure 1. Location of the study area. Frailesca Region, Chiapas (Mexico).

\subsection{Selection of the Study Region and the Farming Styles}

The Frailesca was selected because it is one of the largest maize-producing regions of Chiapas in terms of cultivated area. In this region, the maize agroecosystem is the productive base of the families and is complemented with cattle and smaller species livestock. Maize production is both monocropped and intercropped with other crops.

The farming types for the current study were determined by previous works conducted by Ocaña [6]; Guevara et al. [7] and Guevara et al. [16] in order to focus on three basic management strategies in the Frailesca: Management I, associated to conventional practices; Management II related to traditional practices; Management III, related to intermediate management strategies and placed in-between Management I and II. Moreover, proposition-interactive methods were used, in discussion spaces among experts and farmers as suggested by Hagmann and Guevara [25] and Guevara-Hernández [26] in order to figure out the basic elements of local farming.

Some characteristics from earlier studies were confirmed with a farmer's typology developed as complementary part of this research by considering variables such as: cropped area, labour used, cropping objective, type of seed, fertilizer applied, herbicides used, insecticides spread, machinery used and soil conservation practices implemented (Table 1). Field data was collected from farmers through interviews and surveys. The typology and prior studies were the background to proceed with the current analysis of energy-economic efficiency by focusing on the three maize management modes. Therefore, 35 farms ( 11 for Management I, nine for Management II, and 15 for Management III) were 
selected for the study and monitored during a year for data collection. Such farms represent $10 \%$ of the total (300) used in a parallel study on sustainability assessment.

Table 1. Agroecosystem management modes for maize production in the Frailesca region, Chiapas.

\begin{tabular}{|c|c|c|c|}
\hline $\begin{array}{l}\text { Type of Management } \\
\text { and Technology }\end{array}$ & Management I & Management II & Management III \\
\hline Soil preparation & $\begin{array}{l}\text { Use of small agricultural } \\
\text { machinery plus herbicide }\end{array}$ & $\begin{array}{l}\text { Does not remove soil plus } \\
\text { herbicide }\end{array}$ & $\begin{array}{l}\text { Use of small agricultural } \\
\text { machinery plus herbicide }\end{array}$ \\
\hline Type of seed used & Hybrid & Local $^{1}$ & Hybrid \\
\hline Labour & Family and paid & Family, paid and by invitation ${ }^{2}$ & Family and paid \\
\hline Synthetic inputs & $\begin{array}{l}\text { Intensive use of } \\
\text { herbicides } \\
\text { High amounts of } \\
\text { chemical fertilizers } \\
\text { Generalised use of } \\
\text { insecticides and } \\
\text { fungicides }\end{array}$ & $\begin{array}{l}\text { Less use of herbicides } \\
\text { Lower amount of synthetic } \\
\text { fertilizers and use of local manures } \\
\text { Use of botanical techniques for } \\
\text { pest and diseases control, and } \\
\text { minimal use of synthetic } \\
\text { pesticides }\end{array}$ & $\begin{array}{l}\text { Intensive use of } \\
\text { herbicides } \\
\text { High amounts of } \\
\text { chemical fertilizers } \\
\text { Generalised use of } \\
\text { insecticides and } \\
\text { fungicides }\end{array}$ \\
\hline Other practices & $\begin{array}{l}\text { Small agricultural } \\
\text { machinery for soil } \\
\text { preparation } \\
\text { Monoculture }\end{array}$ & $\begin{array}{l}\text { Soil conservation practices } \\
\text { Intercropping and crop rotation } \\
\text { Manual tools for weed } \\
\text { management and planting } \\
\text { Local knowledge on moon phases } \\
\text { for sowing and harvesting }\end{array}$ & $\begin{array}{l}\text { Soil conservation } \\
\text { practices } \\
\text { Small agricultural } \\
\text { machinery for soil } \\
\text { preparation } \\
\text { Monoculture }\end{array}$ \\
\hline \multicolumn{4}{|l|}{ Socio-economic } \\
\hline Labour & Paid and family & Family, paid and by invitation & Family and paid \\
\hline $\begin{array}{l}\text { Cropping objective (in } \\
\text { order of importance) }\end{array}$ & $\begin{array}{l}\text { Sale and family } \\
\text { consumption }\end{array}$ & $\begin{array}{l}\text { Family consumption, animals and } \\
\text { sale }\end{array}$ & $\begin{array}{l}\text { Sale and family } \\
\text { consumption }\end{array}$ \\
\hline Profit & Medium & High & High \\
\hline Cropping area (average) & 5.70 hectares & 2.66 hectares & 2.53 hectares \\
\hline Land tenure & Ejidal (social) and private & Ejidal (social) & Ejidal and rented \\
\hline $\begin{array}{l}\text { Level of protein } \\
\text { produced } \mathrm{kg} / \mathrm{ha} / \text { year }\end{array}$ & High & Low & Medium \\
\hline Protected forest area & Scarce & High & Medium \\
\hline
\end{tabular}

\subsection{Analysis and Description of the Farming System}

A systemic analysis was conducted by considering all the maize agroecosystem components, its inputs and outputs, as well as the relationships between components according to Guevara et al. [27]. A calendar of agricultural activities to figure out the activities in each production type was drawn and used, according to the methodology described by Geilfus [28], and the annual cropping cycle as reference.

\subsection{Energy Balance}

Regarding the energy balance a method of analysis proposed by Meul et al. [29], Funes [30] and Cervantes [19] was used. The method determines cultivation energy inputs and outputs from products of the system and expresses them in energy units to analyse the flows and obtain the corresponding balances. The documented information was the following: cropped area, type and quantity of food or other products obtained and direct or indirect energy expenditures in production, such as human labour or animal work, fuels used, agrochemicals employed such as fertilizers, pesticides, herbicides and other inputs used in the agroecosystem.

The energy equivalences in Table 2 were used as the basis for calculating energy efficiency. The criteria presented by Márquez et al. [31] were considered for both direct and indirect energy used in maize production. According to this author, direct energy is that contained in inputs: fuel, electricity, 
fertilizers, pesticides, organic fertilizers and biological products. Indirect energy is that associated with processes of manufacture, distribution and maintenance Bowers [32].

Table 2. Energy equivalence of inputs and products analysed in the study.

\begin{tabular}{cccc}
\hline Input & Uni & MJ Unit $^{-1+}$ & Source \\
\hline Human work & Workday & 1.05 & {$[33]$} \\
Animal work & Workday & 7.54 & {$[33]$} \\
Seed (in general) & $\mathrm{Kg}$ & 107.66 & {$[34]$} \\
Diesel & $\mathrm{L}$ & 38.70 & {$[35]$} \\
Gasoline & $\mathrm{L}$ & 34.12 & {$[35]$} \\
Ammonium sulphate $(21 \%)$ & $\mathrm{Kg}$ & 45.03 & {$[36]$} \\
Herbicide & $\mathrm{L}$ & 238.65 & {$[33]$} \\
Insecticide & $\mathrm{L}$ & 184.22 & {$[33]$} \\
Machinery & Hours & 87.92 & {$[34]$} \\
Farm tractor & Hours & 4.25 & {$[37]$} \\
Product (Maize, dry grain) & Kg & 15.31 & {$[30]$} \\
\hline 'The energy equivalents contain direct and indirect energy. &
\end{tabular}

\subsection{Calculation of Indicators for Energy Balance}

In order to compare the three technological modes (Management I, Management II and Management III) for maize production, the method proposed by Funes [33,38] and Pimentel [34] was used for the measurement of energy efficiency in all the selected farms, and to analyse the flow of energy input to the agroecosystem, as well as the amount of output. In addition, this method adapts to the nature of the research. In this sense, different formulas were used for the quantification of energy produced: protein produced/ha, number of people who may eat based on energy, number of people who eat based on protein, energy intensity and energy efficiency:

Energy produced for product $i\left(\mathrm{MJ} \mathrm{ha}^{-1}\right)$ :

$$
E P_{i}=\frac{P_{i} \cdot E E_{i}}{A_{i}}
$$

where: $E P_{i}$-Energy produced for the $i$ thproduct, $P_{i}$-total production, $E E_{i}$-energy equivalent and $A_{i}$-total area for the corresponding product.

Protein produced for a product $\left(\mathrm{Kg} \mathrm{ha}^{-1}\right)$ :

$$
P P_{i}=\frac{P_{i} \cdot E P_{i}}{A_{i}}
$$

where: $P P_{i}$-Protein produced for the $i^{\text {th }}$ product, $P_{i}$-Total production, $E P_{i}$-Protein equivalence and $A_{i}$ - total area for the corresponding product.

Number of people fed with energy (People ha ${ }^{-1}$ ):

$$
P A E=\frac{\sum_{i=1}^{2} E P_{i}}{R E 1}
$$

where: $P A E$-People fed by the system with energy per unit of area, $E P_{i}$-Energy produced by product $i$ and RE1-Energy requirement of one person for one year.

Number of people fed with protein (People ha ${ }^{-1}$.year):

$$
P A P=\frac{\sum_{i=1}^{2} P P_{i}}{R P 1}
$$

where: $P A P$-People fed by the system with protein per unit of area, $P P_{i}$-Protein produced by product $i$ and $R P 1$-energy requirement of one person for one year. 
Energy intensity (MJ.kg-1) energy required per $\mathrm{kg}$ of food produced:

$$
I E=\frac{E U T}{P T}
$$

where: IE-Energy intensity, EUT-Total used energy, sum of inputs multiplied by their energy equivalents and $P T$-total production in $\mathrm{kg}$.

Energy yield (kg.MJ ${ }^{-1}$ ) Production obtained per MJ consumed:

$$
R E=\frac{P T}{E U T}
$$

where: $R E$-energy yield, EUT - Total used energy, sum of inputs multiplied by their energy equivalents and $P T$-Total production in $\mathrm{kg}$.

Used energy efficiency, Energy produced by each unit of energy consumed.

$$
E E=\frac{E P T}{E U T}
$$

where: EE-Energy efficiency, EUT-Total used energy, sum of inputs multiplied by their energy equivalents and $E P T$-Total produced energy, sum of products multiplied by their energy equivalents.

\subsection{Economic Efficiency of the Farming System}

To calculate economic efficiency, production costs as well as incomes from sale of the harvest were considered. With data on incomes and expenditures, the Benefit/Cost ratio was calculated as the indicator of economic efficiency using the formula:

$$
\text { Benefit } / \text { Cost }=\text { Incomes } / \text { Costs }
$$

Field data were obtained through direct interviews with farmers. The costs of agricultural activities, inputs used in each activity, labour, economic value of crop yields and type of product obtained were considered in order to evaluate energy inputs and outputs [39].

\section{Results and Discussion}

\subsection{Characteristics of the Maize Production Modes}

The three management modes studied (Management I, Management II and Management III) were based on mono-cropped maize. They are carried out in one annual cycle and are rainfed; that is, moisture is provided during the rainy season from June to December. Traditional work techniques are used with typical tools such as the "coa" (planting stick), hoe, machete and simple equipment such as sprayers for applying chemical products. For harvesting, maize de-graining machines are used.

The use of agrochemicals is common to the three management types studied, but they differ in magnitude of use. Management I is based on mechanised tillage, use of hybrid seed and high quantities of agrochemicals, while the other two modes (Management II and Management III) use local varieties, coinciding with the results published by Damián et al. [40] and Delgado et al. [12].

The quantity of industrialised inputs used differ in the three management types (Table 3). Management I is characterised by intensive use of herbicides, insecticides, fertilizers and fungicides, from seed treatment to crop growth and development. In the case of Management II, insecticides are used to treat seed before sowing to control the borer Spodoptera frugiperda Smith during crop growth. Traps with natural attractants are also used. In management III, herbicides are used in larger quantities than in the other two modes, as well as insecticides, mechanised tillage and hybrid seed. In all cases, growers sell most of the grain immediately after harvest. The rest is stored either on the cob or as grain 
for home consumption and feed for backyard animals. By type and quantity of agrochemicals used, the conventional and mixed modes are those that use more chemical products.

Table 3. Inputs used in a crop cycle/hectare for each type of maize management.

\begin{tabular}{|c|c|c|c|c|c|c|c|c|}
\hline \multirow{3}{*}{ Input } & \multirow{3}{*}{$\begin{array}{c}\text { Unit of } \\
\text { Measure }\end{array}$} & \multicolumn{6}{|c|}{ Amount of Inputs Used ha- } & \multirow{3}{*}{ Sig. } \\
\hline & & \multicolumn{2}{|c|}{ Management I } & \multicolumn{2}{|c|}{ Management II } & \multicolumn{2}{|c|}{ Management III } & \\
\hline & & Mean & S.E. & Mean & S.E. & Mean & S.E. & \\
\hline Seed (maize) & $\mathrm{Kg}$ & 20 & 0.000 & 20 & 0.000 & 20 & 0.000 & ns \\
\hline Diesel & $\mathrm{L}$ & 10 & 1.612 & 8 & 2.646 & 10 & 1.648 & ns \\
\hline Gasoline & $\mathrm{L}$ & $15 \mathrm{a}$ & 3.435 & $10 \mathrm{~b}$ & 1.936 & $15 \mathrm{a}$ & 2.392 & 0.00 \\
\hline Ammonium Sulphate $21 \%$ & $\mathrm{Kg}$ & $800 \mathrm{a}$ & 63.246 & $600 \mathrm{~b}$ & 75.00 & $800 \mathrm{a}$ & 70.711 & 0.00 \\
\hline Glyphosate & $\mathrm{L}$ & $3.5 \mathrm{a}$ & 0.5477 & $1.5 \mathrm{~b}$ & 0.500 & $3 a$ & 0.6814 & 0.00 \\
\hline Paraquat & $\mathrm{L}$ & $5 \mathrm{a}$ & 0.922 & $1 \mathrm{c}$ & 0.500 & $3 \mathrm{~b}$ & 0.756 & 0.00 \\
\hline 2-4 D amine & $\mathrm{L}$ & $3 a$ & 0.447 & $1 \mathrm{c}$ & 0.000 & $2 \mathrm{~b}$ & 0.655 & 0.00 \\
\hline Paraquat + Diuron & $\mathrm{L}$ & $0 \mathrm{c}$ & 0.000 & $3 a$ & 0.500 & $2 \mathrm{~b}$ & 0.655 & 0.00 \\
\hline Methyl parathion & $\mathrm{L}$ & $2 b$ & 0.742 & $1 \mathrm{c}$ & 0.433 & $3 a$ & 0.463 & 0.00 \\
\hline Aluminium phosphorus & Tablet & $3 a$ & 0.632 & $0 \mathrm{c}$ & 0.000 & $2 \mathrm{~b}$ & 0.756 & 0.00 \\
\hline Cypermethrin & $\mathrm{L}$ & $3 a$ & 0.775 & $1 \mathrm{c}$ & 0.707 & $2 \mathrm{~b}$ & 0.756 & 0.00 \\
\hline Mancozeb & $\mathrm{kg}$ & $3 a$ & 0.632 & $1 \mathrm{c}$ & 0.707 & $2 \mathrm{~b}$ & 0.756 & 0.00 \\
\hline
\end{tabular}

Different letters in the same rows indicate statistical difference $(p \leq 0.05)$; Duncan (1955). S.E.: Standard error; ns: Not significant, Sig: Significance.

The use of fertilizers is another common aspect to the three types of maize agroecosystem management. The difference lies in the quantity used; Management II uses the least (Table 3). This agrees with [40], who mentions that the use of herbicides and fertilizers is common to all models of maize production, both Management I and Management III. However, they differ in the quantities used, in efficient use of nitrogen and in GGE [14].

Management II uses $20 \mathrm{~kg} \mathrm{ha}^{-1}$ of a landrace seed known locally as "macho". Seed is obtained from the last harvest or is acquired from another grower of the same community if for some reason the seed is lost. The cultivated area is generally one hectare with an average yield of $3411.1 \mathrm{~kg} \mathrm{ha}^{-1}$. Of the harvest, $93.8 \%$ is sold and the rest is used for home consumption and animal feed.

The system's largest energy costs are from external sources, from acquisition of herbicides, insecticides, fungicides, fertilizers and fuel used in land preparation and de-graining ears. This coincides with Iermanó and Sarandón [41], who pointed out that agricultural production generates an increase in the use of fossil fuel and its derivates. The energy from labour is that of the grower himself, and only for some activities, such as sowing, fertilisation and de-graining, paid labour is required. During the entire crop cycle, 137 workdays/ha are needed; of these, only $15 \%$ is paid since the rest is supplied by the grower or his family.

Management I uses hybrid seed, $20 \mathrm{~kg} \mathrm{ha}^{-1}$. On average, one hectare is planted for an average yield of $4727.2 \mathrm{~kg} \mathrm{ha}^{-1}$, of which $95.1 \%$ is sold and the rest is used for home consumption and feeding the animals, generally, backyard poultry. Most of the energy used in the system comes from external sources through acquisition of herbicides, insecticides and fertilizers. Labour used is 110 workdays/ha, of which $23 \%$ is paid the rest is family labour.

Management III is based on hybrid varieties as well as landraces. The amount of seed necessary to plant one hectare is $20 \mathrm{~kg}(62,500 \mathrm{seeds} / \mathrm{bag})$. The variety used is often attacked by pests and diseases during the season of intense rains. Nevertheless, average yield is $4033.3 \mathrm{~kg} \mathrm{ha}^{-1}, 99.1 \%$ of which is sold. Like the other two systems, most of the energy expenditure comes from external sources, which include herbicides, fertilizers and fuel. The labour needed is 117 workdays/ha, of which $19 \%$ is paid.

\subsection{Productive Cycle and Types of Management}

The calendar of agricultural activities is similar for the three management types. The crop cycle begins with sowing in June and early July after the rainy season has begun. In March and April, "rastrojeo" (grazing animals in the plots where maize had been planted) is practiced, anti-fire gaps 
are constructed, residues are burned and herbicide is applied. In the three modes of agroecosystem management, fertilizer is applied twice, in July and August (20 and 40 days after sowing), while herbicides are applied during June and July. Harvest is in December and occasionally postponed until January or February of the following year. One article [42] gives a similar description and highlights the harvest for the sale of grain and the care of seeds for the next crop cycle as important aspects.

\subsection{Use of Labour}

Availability and use of labour in agricultural activities for each mode of production studied vary and depend on both the activity and the day wages paid by the grower (Figure 2). Depending on the activity, a full day of work is $6 \mathrm{~h}$, for which 120 pesos (6 USD) is paid. For de-graining the maize, work is around one hour, and the full day is paid. There are also communities where this activity is done by invitation; the practice is collaborative and rotational for the grower that requires additional labour at an agreed moment. In the case of labour provided by the grower of each production unit, a workday can last $10 \mathrm{~h}$, which means much longer workdays, which increase the energy expenditure for the production system. When the land where the maize will be planted is burned, the grower may work for $24 \mathrm{~h}$ to take the necessary measures to contain the fire and comply with the regulations established by the National Commission of Natural Protected Areas (CONANP, abbreviation in Spanish).

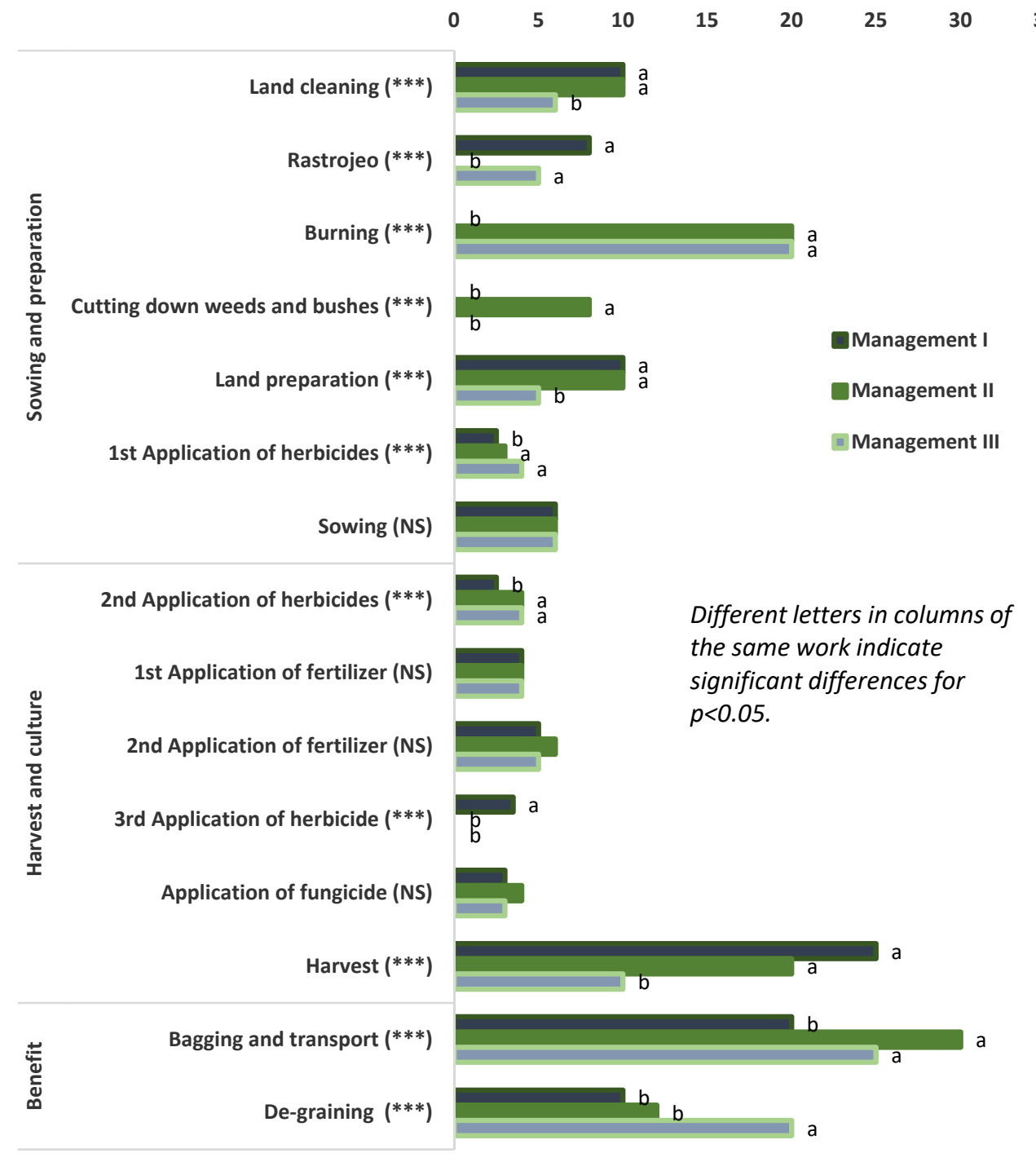

Figure 2. Labour needed for agricultural activities in three management modes for maize production (workday/h) in the Frailesca region (Chiapas). ${ }^{* * *}$ Significant; NS: Not significant. 
The activities carried out in each management type are differentiated by the number of working days (6 h/day) used: Management I (110 days/cycle), Management II (137 days/cycle) and Management III (117 days/cycles). Namely, 660 h, 822 h and 702 h, respectively, are needed for maize production during a crop cycle. This is because in Management II, more working days are used for grain-bagging and transport, but also because farms are located far from the sales centre. Nonetheless, the three management modes share common points, e.g., in the number of workings days used for sowing (6), fertilizers application (5) and fungicides application (3). These similarities are based on established social representations among the farmers. In other words, these variables are a kind of common factor for managing strategies in the Frailesca and based on a shared and little-questioned knowledge. The results for Management I coincide with those reported by Delgado et al. [12] and Purroy et al. [43], who found that within conventional management, more machinery is used and the need for labour is reduced.

Management II concentrates $51 \%$ (70 workdays) of the total days employed for burning, harvesting, bagging and transport; moreover, Management III invests $47 \%$ (55 workdays) of days for the same activities. The results show that these activities are the most-labour demanding in both management types. This agrees with Purroy et al. [43] in relation to labour demands for harvest, bagging and transport.

\subsection{Energy Balance}

From an energy perspective, the three modes of managing the maize agroecosystem have an efficiency of one, indicating their energy feasibility. Management II had the lowest energy use efficiency (4.65 MJ) because it generated a high energy expenditure, with $11,831.18 \mathrm{MJ} \mathrm{ha}^{-1}$, and lower yield than the other management modes. These results contrast with those found by Funes et al. [44], who indicated that in food production agroecological systems in Cuba, the least diversified systems were the least productive, but they tended to be more energy efficient [45]. However, in the Frailesca mono-cropped maize predominates under any management type. Additionally, the energy efficiencies of Management I (6.04 MJ) and Management III (6.47 MJ) are very close to that reported by Alemán and Brito [21] for mono-cropped maize with conventional management methods. In this sense, both systems (Management I and Management III) increased the use of energy inputs, suggesting that these inputs are used in order to be more efficient. This also coincides with Sánchez and Romero [20]. However, Pimentel [46] stated that average energy use efficiency for maize is $41.84 \mathrm{MJ}$, produced for each invested MJ. This indicates that even under this criterion, in general, the three modes of management exhibit low energy use efficiency. For this reason, the study of agroecosystem energy use efficiency can be used as a tool for characterizing and typifying these systems, according to Purroy et al. [47] and Stark et al. [48].

The analysis of energy use intensity for the management types (I, II and III) in the agroecosystem revealed that to produce one kilogram of maize, 2.87, 3.61 and 2.63 MJ, respectively, are required. This shows that most farmers depend on fossil energy and on agrochemicals, coinciding with results obtained by Pimentel and Pimentel [49]. Thus, the three management modes are inefficient in terms of fossil energy use, which could be explained by deterioration of the soil, timing of input application and distribution of rainwater at the critical stages of growth and development of the agroecosystem. In synthesis, these systems are not sustainable in the long term because the soil is constantly being degraded.

In terms of energy from agrochemicals, more than $50 \%$ of the energy expenditure depends on that supplied by ammonium sulphate fertilizer. For the three types of the maize agroecosystem management (I, II and III), around 36,024, 27,018 and 36,024 MJ, respectively, are used. This coincides with IDAE [37], who demonstrated that nitrogen fertilizers are those that demand more than half the energy cost of a crop.

Moreover, the higher energy cost is due to inputs such as herbicides and insecticides required for pest and disease control. However, the energy contribution of these expenditures tends to be 
compensated by the elimination of competition for the crop and of damage to the maize plant, resulting in higher yield. Regarding the other inputs, such as fuel, the energy cost is low in the three systems since it is only consumed by the ear de-grainer and the tractor for preparing the soil and occasionally to transport the harvest. Valdés et al. [50], in a study on energy use efficiency of diverse agroecosystems in Cuba, showed that the energy balance is significantly affected by external inputs needed to maintain production.

Based on yields, Management I can feed more people per unit of area, in terms of both energy and protein, than Management II or Management III (Table 4). This indicator has environmental significance since growing social demand for food imposes a need to obtain yields that are sufficient to slow the expansion of the agricultural frontier. These results coincide with Valdés et al. [50], who stated that in energy terms mono-cropping high yielding crops produces large quantities of energy that can feed more people per unit of area. Schiere et al. [51] showed that the number of people that one hectare of land planted with a single crop (maize) can feed is 10.4, as energy source, and 5.4, as protein source.

Table 4. Energy balance and potential for energy and protein production within three management modes for the maize agroecosystem.

\begin{tabular}{|c|c|c|c|c|c|c|c|}
\hline \multirow{2}{*}{ Production Factors } & \multicolumn{2}{|c|}{ Management I } & \multicolumn{2}{|c|}{ Management II } & \multicolumn{2}{|c|}{ Management III } & \multirow[t]{2}{*}{ Sig. } \\
\hline & \multicolumn{2}{|c|}{ Mean S.E. } & \multicolumn{2}{|c|}{ Mean S.E. } & \multicolumn{2}{|c|}{ Mean S.E. } & \\
\hline Planted area (ha) & 1 & & 1 & & 1 & & ns \\
\hline Yield $\left(\mathrm{kg} \mathrm{ha}^{-1}\right)$ & $4727.2^{\mathrm{a}}$ & 368.75 & $3411.1^{b}$ & 407.66 & $4033.3^{\mathrm{a}}$ & 315.77 & 0.069 \\
\hline Energy produced (EP) $\left(\mathrm{MJha}^{-1}\right)$ & $73,760.18$ & 6044.17 & $54,982.67$ & 6682.08 & $65,387.8$ & 5175.92 & ns \\
\hline Protein produced $\left(\mathrm{Kg} \mathrm{ha}^{-1}\right)$ & 465.85 & 41.77 & 362.53 & 46.17 & 434.30 & 35.77 & ns \\
\hline \multicolumn{8}{|l|}{ Number of people fed ha-1/year } \\
\hline Maize & $24.06^{\mathrm{a}}$ & 1.88 & $17.36^{\mathrm{c}}$ & 2.08 & $20.53^{b}$ & 1.36 & 0.069 \\
\hline Protein sources & 23.40 & 2.09 & 18.21 & 2.31 & 21.82 & 1.79 & ns \\
\hline Energy consumed (EC) & $12,177.13^{a}$ & 439.98 & $11,831.18^{a}$ & 486.42 & $10,099.83^{b}$ & 376.78 & 0.002 \\
\hline Human and animal work (MJ ha ${ }^{-1}$ ) & 260.72 & 24.05 & 268.66 & 26.59 & 304.73 & 20.60 & ns \\
\hline Inputs used $\left(\mathrm{MJ} \mathrm{ha}^{-1}\right)$ & $11,916.4^{\mathrm{a}}$ & 430.74 & $11,562.51^{a}$ & 476.20 & $9795.44^{b}$ & 368.86 & 0.001 \\
\hline Energy intensity $\left(\mathrm{MJkg}^{-1}\right)$ & $2.87^{\mathrm{a}}$ & 0.30 & $3.61^{\mathrm{a}}$ & 0.33 & $2.63^{b}$ & 0.25 & 0.034 \\
\hline Energy yield $\left(\mathrm{kgMJ}^{-1}\right)$ & $0.395^{\mathrm{a}}$ & 0.00 & $0.305^{\mathrm{b}}$ & 0.00 & $0.430^{\mathrm{a}}$ & 0.00 & 0.039 \\
\hline Energy use efficiency (EP/EC) & $6.04^{\mathrm{a}}$ & 0.52 & $4.65^{b}$ & 0.57 & $6.47^{\mathrm{a}}$ & 0.44 & 0.038 \\
\hline
\end{tabular}

Different letters in rows indicate statistical difference ( $p \leq 0.05)$; Duncan (1955). S.E.: Standard error: ns: not significant. Sig: Significance.

\subsection{Benefit-Cost Ratio}

The total cost of Management I is higher than the others (Figure 3), mostly due to the high price of the seed, fertilizers, land preparation and labour that the maize agroecosystem demands. Labour and fertilizers account for $27 \%$ and $21.8 \%$, respectively, of the total production cost. Management II and Management III present the same tendency. The costs of agrochemicals make maize production more expensive under the three management modes in the study area. The three types of management (I, II and III) spend 54.72, 55.64 and 51.83\%, respectively, of the total production cost on agrochemicals, which has negative implications for the environment and indicates that they are unsustainable practices, even though the profit margins may justify them economically. 


\section{Management I}

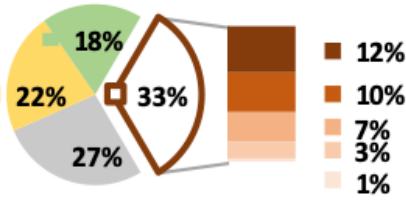

Management II

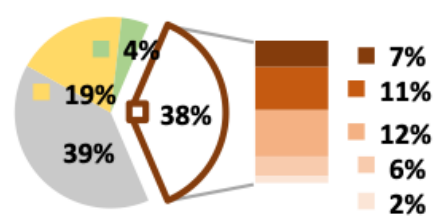

Management III

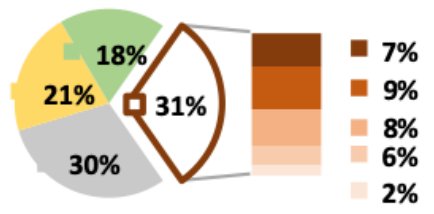

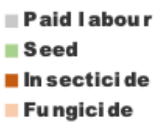

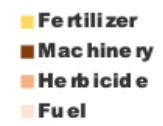

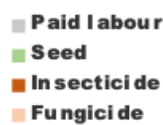

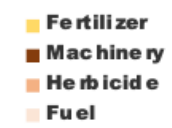

Fertili zer

Mac hine ry

Hemicide

Fuel

Figure 3. Structure and percentages of economic expenses in three management modes for maize production in the Frailesca region (Chiapas).

By percentage of commercialised harvest, grain yield, and sale price, Management I obtains the highest economic gains (Table 5). This is due not only to higher yields, but also to the $95.1 \%$ of the harvest that is sold. In contrast, Management II commercialises 93.8\%, while Management III obtains good grain yield and commercialises $99.1 \%$, and is second place in terms of economic income.

Table 5. Yields and economic income by type of maize production in the Frailesca (Chiapas).

\begin{tabular}{cccccc}
\hline $\begin{array}{c}\text { Mode of } \\
\text { Production }\end{array}$ & $\begin{array}{c}\text { Yield } \\
\text { (kg/ha) }\end{array}$ & $\begin{array}{c}\text { Quantity } \\
\text { Commercialised (kg) }\end{array}$ & $\mathbf{\%}$ & $\begin{array}{c}\text { Price/kg } \\
\text { (pesos) }\end{array}$ & $\begin{array}{c}\text { Income/ha } \\
\text { (pesos) }\end{array}$ \\
\hline Management I & 4727.2 & 4500 & 95.1 & 4.00 & 18,000 \\
Management II & 3411.1 & 3200 & 93.8 & 4.20 & 13,440 \\
Management III & 4033.3 & 4000 & 99.1 & 4.10 & 16,400 \\
\hline
\end{tabular}

These results coincide with those obtained by Miranda et al. [52] and Mandal et al. [53], who stated that mono-cropped maize systems have better yields in both economic gains and energy. Management I and Management II have a better benefit/cost ratio of 1.56, while Management III has one of 1.49. This means that, according to the economic feasibility analysis of the three management modes, Management I and Management II are more feasible, with a profit margin of 0.56 per invested peso (Table 6).

Table 6. Economic feasibility analysis based on the benefit/cost ratio of three maize production types.

\begin{tabular}{cccc}
\hline & Management I & Management II & Management III \\
\hline Income $(\$)$ & 18,000 & 13,400 & 16,400 \\
Expenditure $(\$)$ & 11,485 & 8565.8 & $11,002.7$ \\
Benefit/cost & 1.56 & 1.56 & 1.49 \\
\hline
\end{tabular}

Several factors can affect economic feasibility, among which are high costs of external inputs required by the three management modes and labour costs versus prices of the product at the time of commercialisation. Additionally, low crop yields limit the energy use and economic efficiency of these systems.

The three different management modes make use of fossil energy, one with greater intensity (Management I), and has long-term consequences on natural resources, especially on the soil, because 
it contributes to its degradation and automatically leads to a production capacity reduction. In that sense, it is important to carry out soil conservation practices as indicated by Purroy et al. [54] in order to promote the soil biodiversity and enhance the overall productivity of tropical agroecosystems. Therefore, energy efficiency should be relaying on a better use of renewable energy, because in Mexico, during the last 10 years the use of oil (sub) products in the agriculture sector has significantly increased $[55,56]$. Despite national policies are recently promoting renewable energies and products in agriculture but in an incipient and non-generalised strategy [57,58].

\section{Conclusions}

Three maize production strategies were confirmed in the Frailesca, Chiapas (Mexico): Management I, II and III, which are practiced mostly under smallholder conditions. They use landrace and hybrid seeds as well as intensive use of labour, whose economic costs oscillate between 26.99 and $39.69 \%$ of the total production cost. Management III was found to be the most efficient from an energy perspective, while Management I has the highest capacity of protein and can feed a larger number of people per hectare in one year, although it uses larger quantities of industrial inputs in its production process. From an economic point of view, Management I and Management II were more efficient in the benefit-cost relationship with 1.56 pesos; for each invested peso, there is a profit margin of 0.56 peso. Although Management II did not present a high yield condition, its low production cost made it efficient economically.

The inputs and supplies from industrial origins and non-renewable sources used in the maize agroecosystem of the Frailesca are different in the three technological modes here analysed. Management I is characterised by the intensive use of herbicides, insecticides, fertilizers and fungicides, from the seed treatment to the growth and crop development. In Management II, insecticides are used for the seed treatment before sowing. In Management III, herbicides are commonly used in higher quantities-as well as insecticides - than the previous management modes; mechanisation (small equipment) for soil preparation and commercial seeds are also utilised. In the three management modes, most of the farmers sell the maize immediately after harvest; the remaining maize is stored either on the cob or as grain for the family's own consumption and used for feeding barn animals. Regarding the type and quantity of agrochemicals, Management I and Management III use the most. The use of fertilizers is another common and shared element among the three management strategies and particular differences lie in the quantity used, being Management II where minimum applications are required.

Author Contributions: Conceptualisation, F.G. and D.R.A.; data curation, R.P., M.A.L.O. and L.A.R.; formal analysis, F.B.M. and M.A.L.O.; investigation, F.B.M. and C.E.A.; Methodology, F.G., L.A.R. and D.R.A.; software, M.A.L.O.; supervision, F.G. and C.E.A.; Validation, R.P. and D.R.A.; Writing original draft, F.B.M. and F.G.; Writing-review and editing, F.B.M., F.G., M.A.L.O. and L.A.R. All authors have read and agreed to the published version of the manuscript.

Funding: This article was supported by the Programa para el Desarrollo Profesional Docente (PRODEP) from the Ministry of Education of Mexico (SEP), which provided the funds to get it published. The authors are very grateful to this institution.

Acknowledgments: This article is part of the doctoral dissertation entitled "Sustainability of the maize (Zea mays L.) agroecosystem in the Frailesca region, Chiapas, Mexico" of the first author, who is grateful to the Universidad Autónoma de Chiapas for its support and the opportunity to pursue the doctoral studies, PRODEP programme for the scholarship granted and the farmers who directly and indirectly participated in this research.

Conflicts of Interest: The authors declare that there is no conflict of interests between them and the journal, or to any other instance or institution related to this research. This paper, due to the type of field work carried out, does not present any ethical or bioethical implications. Finally, if there is any additional data or information required, it will be provided by the first author or the corresponding author. 


\section{References}

1. Perales, H.R.; Benz, B.F.; Brush, S.B. Maize diversity and ethnolinguistic diversity in Chiapas, Mexico. Proc. Natl. Acad. Sci. USA 2005, 102, 949-954. [CrossRef] [PubMed]

2. Ferraro, O.D. Energy use in cropping systems: A regional long-term exploratory analysis of energy allocation and efficiency in the Inland Pampa (Argentina). Energy 2012, 44, 490-497. [CrossRef]

3. Hellin, J.; Erenstein, O.; Beuchelt, T.; Camacho, C.; Flores, D. Maize stover use and sustainable crop production in mixed crop-livestock systems in Mexico. Field Crops Res. 2013. [CrossRef]

4. Servicio de Información Agroalimentaria y Pesquera (SIAP). Atlas Agroalimentario Servicio de Información Agroalimentaria y Pesquera; Secretaría de Agricultura, Ganadería, Desarrollo Rural, Pesca y Alimentación (SAGARPA): Mexico City, Mexico, 2017; Available online: http://www.siap.gob.mx/ (accessed on 2 February 2020).

5. Hernández-Ramos, M.A.; Rodríguez-Larramendi, L.A.; Guevara-Hernández, F.; Rosales-Esquinca, M.D.L.Á.; Pinto-Ruiz, R.; Ortiz-Pérez, R. Molecular characterization of local maize varieties from the Biosphere Reserve La Sepultura, Mexico. Agron. Mesoam. 2017, 28, 69-83. [CrossRef]

6. Ocaña, J.M.J. Estudio Socioeconómico y Ambiental del uso y Manejo del Rastrojo en los Sistemas Maíz-ganadería en la Region Frailesca, Chiapas. Master's Thesis, Universidad Autónoma de Chiapas, Tuxtla Gutiérrez, Mexico, 2015; p. 110.

7. Guevara, H.F.; Delgado, R.F.; Arias, L.M.; Rodríguez, L.L.; Ortiz, P.R.; Delgado, R.J.A.; Venegas, V.J.A.; Pinto, R.R. Comparative energy-economic analysis of the maize agroecosystem under conventional and conservation practices in the Frailesca región, Chiapas, Mexico. Rev. Fac. Agron. Univ. Zulia 2018, 35, 343-364.

8. Denoia, J.; Monticos, S. Energy balance in field vegetable crops in Rosario (Santa Fe, Argentina). Cienc Docencia Tecnol. 2010, XXI, 145-157. Available online: http://www.redalyc.org/articulo.oa?id=14515335007 (accessed on 3 December 2019).

9. Denoia, J.; Vilche, M.; Montico, S.; Bonel, B.; Di Leo, N. Descriptive Analysis of the Evolution of the Technological Models Prevalent in Zavalla District (Santa Fe), from an Energetic Perspective. Cienc. Docencia Tecnol. 2006, XVII, 211-226.

10. Bonel, B.; Montico, S.; di Leo, N.; Denoia, J.; Vilche, M. Energy analysis of the land units in a rural basin. Rev. FAVE Cienc. Agrar. 2006, 4, 37-47.

11. Rodríguez-Larramendi, L.; Guevara-Hernández, F.; Ovando-Cruz, J.; Marto-González, J.R.; Ortiz-Pérez, R. Growth and harvest index of local maize varieties (Zea mays L.) in communities of the Frailesca region of Chiapas, Mexico. Cultiv. Trop. 2016, 37, 137-145. [CrossRef]

12. Delgado-Ruiz, F.; Guevara-Hernández, F.; Acosta-Roca, R. Farmers' criteria for maize (Zea mays L.) selection in Villaflores and Villa Corzo, Chiapas, Mexico. Cienc. UAT 2018, 13, 123-134. [CrossRef]

13. Corporación Educativa para el Desarrollo Costarricense (CEDECO). Emisión de Gases con Efecto Invernadero y Agricultura Orgánica; CEDECO: San José, Costa Rica, 2007; p. 59.

14. Vergara, R.D.R.G.; Díaz, R.Á.; Alvarez, P.A. Effect of Nitrogen Fertilization on Maize Crop to Characterize Greenhouse Gas Emissions; Working Papers; Universidad Nacional Abierta y a Distancia: Bogotá, Colombia, 2017.

15. Vilche, S.M.; Denoia, J.; Montico, S.; Bonel, B.; Dileo, N. Energy usage in agropecuarian systems at the Argentinian district of Zavalla, Santa Fe. Rev. Científica Agropecu. 2006, 10, 7-19.

16. Guevara-Hernández, F.; Rodríguez-Larramendi, L.A.; Hernández-Ramos, M.A.; Fonseca-Flores, M.A.; Ruiz, R.P.; Reyes-Muro, L. Energy and economic efficiency of maize in the buffer zone of the Biosphere Reserve "La Sepultura", Chiapas, Mexico. Rev. Mex. Cienc. Agrícolas 2015, 6, 1929-1941. [CrossRef]

17. Hernández, R.M.A.; Hernández, F.G.; Larramendi, L.A.R.; Esquinca, M.Á.R.; Castro, H.G.; López, A.H.; Ruiz, R.P.; Jonapá, F.J.M. Eficienciaenergética y económica del proceso de producción del sistema maíz en una comunidad rural. In Naturaleza-Sociedad: Reflexiones Desde la Complejidad; Flores, A.C., Báez, P.A.O., Rodríguez, A.D., Rábago, F.G., Eds.; CIISDER, Centro de Investigaciones Interdisciplinarias sobre Desarrollo Regional, Universidad Autónoma de Tlaxcala: Tlaxcala, Mexico, 2003; pp. 130-150, ISBN 978-607-7698-98-2.

18. Dussi, M.C.; Fernández, C.; Flores, L. Towards sustainable use of energy in agroecosystems. Cuad. Agroecol 2018, 13, 9.

19. Cervantes, O.A. Transformación agroecológica en el cantón de Mora en Costa Rica y emigraciónindígenahuetar (1900-1955). Rev. Hist. 2016, 74, 116. 
20. Sánchez-Morales, P.; Romero-Arenas, O. Fossil fuels and $\mathrm{CO}_{2}$ traditional milpa and monoculture maize systems in Tlaxcala, Mexico. Rev. Mex. Cienc. Agrícolas 2017, 4, 919-932.

21. Pérez, R.A.; Flores, J.C.B. Balance energetic en dos sistemas de producción de maíz en las condiciones de Cuba. Cent. Agrícola. 2003, 30, 84-87.

22. Pervanchon, F.; Bockstaller, C.; Girardin, P. Assessment of energy use in arable farming systems by means of an agro-ecological indicator: The energy indicator. Agric. Syst. 2002, 72, 149-172. [CrossRef]

23. Corporación Educativa para el Desarrollo Costarricense (CEDECO). Agricultura Orgánica y Gases con EfectoInvernadero; CEDECO: San José, Costa Rica, 2005; p. 27.

24. Instituto Nacional de Estadística, Geografía e Informática (INEGI). Anuario Estadístico de los Estados Unidos Mexicanos 2011/Instituto Nacional de Estadística, Geografía e Informática; INEGI: Aguascaliente, Mexico, 2012; p. 155.

25. Hagmann, J.; Guevara, H. Aprendiendo Juntos Para el Cambio: La Facilitación de Innovaciones Para el Manejo Sustentable de Recursos Naturales y el Desarrollo Rural a Través de Procesos Participativos; Serie Estudios de Caso; Red de Estudios para el Desarrollo Rural A.C. y Fundación Rockefeller, Oaxaca de Juárez: Oaxaca, Mexico, 2004; p. 153.

26. Guevara-Hernández, F. ¿Y después qué?: Action-Research and Ethnography on Governance, Actors and Development in Southern Mexico; Technology and Agrarian Development Group, Department of Social Sciences, Wageningen University and Research Centre: Wageningen, The Netherlands, 2007; p. 223.

27. Guevara, H.F.; Rodríguez, L.L.; Arias, L.M.; Gómez, C.H.; Fonseca, F.M.; Pinto, R.R.; Ponce, P.I.; Jonapá, M.F.; Carbonell, C.J.; Hernández, L.A.; et al. Metodología Para el Desarrollo de Procesos de Innovación Local a Través de la Investigación Acción; IIA Jorge Dimitrov: Bayamo, Cuba, 2011; p. 27.

28. Geilfus, F. 80 Herramientas Para el Desarrollo Participativo; Diagnóstico, Planificación Monitoreo y Evaluación; IICA: San José, CA, USA, 1997; p. 217.

29. Meul, M.; Nevens, F.; Reheul, D.; Hofman, G. Energy use efficieny of specialised dairy, arable and pig farms in Flanders. Agric. Ecosyst. Environ. 2007, 199, 135-144. [CrossRef]

30. Funes, M.F. Agricultura con Futuro, la Alternativa Agroecológica Para Cuba; Estación Experimental Indio Hatuey, Universidad de Matanzas: Matanzas, Cuba, 2009; p. 176.

31. Márquez, M.; Valdés, N.; Ferro, M.E.; Paneque, I.; Rodríguez, Y.; Chirino, E.; Gómez, L.M.; Vargas, D. Análisis agroenergético de tipologías agrícolas en La Palma. In Innovación Agroecológica, Adaptación y Mitigación del Cambio Climático; Ríos, L.H., Vargas, V.D., Funes, M.F., Eds.; Instituto Nacional de Ciencias Agrícolas (INCA): San José de las Lajas, Cuba, 2011; p. 248.

32. Bowers, W. Agricultural field equipment. In Energy in the World Agriculture, Energy in Farm Production; Fluck, R.C., Ed.; Elsevier: Amsterdam, The Netherlands, 1992; Volume 6, pp. 117-129.

33. Funes, M.F. Sistema Para el Análisis de la Eficiencia Energética de Fincas Integrales; IIPF (Instituto de Investigación de Pastos y Forrajes): Matanzas, Cuba, 2001.

34. Pimentel, D. Environmental and economic costs of the application of pesticides primarly in the United States. Environ. Dev. Sustain. 2005, 7, 229-252. [CrossRef]

35. Masera, O.; Astier, M. Energía y Sistema Alimentario en México: Aportaciones de la Agricultura Alternativa, en Agroecología y Desarrollo Agrícola en México; Universidad Autónoma Metropolitana: Xochimilco, Mexico, 1993.

36. Instituto para la Diversificación y Ahorro de la Energía (IDAE). Ahorro, Eficiencia Energética y Fertilización Nitrogenada; IDAE: Madrid, Spain, 2007; p. 44.

37. Fluck, C.R. Energy in World Agriculture: Energy in Farm Production; Agricultural Engineering Department, Institute of Food and Agricultural Sciencies, University of Florida: Gainesville, FL, USA, 1992; p. 384.

38. Funes, F.; Monzote, F. Eficiencia Energetica en Sistemas Agropecuarios: Elementos Teoricos y Practicos Para el Calculo y Análisis Integrado; Estación experimental “Indio Hatuey", Universidad de Matanzas, Ministerio de Educación Superior: Matanzas, Cuba, 2009; p. 38.

39. Centro Internacional de Mejoramiento de Maíz y Trigo (CIMMyT). La Formulación de Recomendaciones a Partir de Datos Agronómicos: Un Manual Metodológico de Evaluación Económica; CIMMyT: Mexico City, Mexico, 1988; p. 86, ISBN 968-6127-24-0.

40. Damián, H.M.; Ramírez, V.B.; Aragón, G.A.; Huerta, L.M.; Sangerman, J.; Romero, A. Handling of maize in the state of Tlaxcala, Mexico: Between the conventional and the agroecological. Rev. Latinoam. Recur. Nat. 2010, 6, 67-76. 
41. Iermanó, M.J.; Sarandón, S.J. Eficiencia energética de cultivos anuales en dos tipos de agroecosistemas de la Región Pampeana Argentina. In Proceedings of the Memorias del V Congreso Latinoamericano de Agroecología, La Plata, Argentina, 7-9 October 2015; p. 5.

42. Aguilar, J.C.E. Informe final del estudiotécnico: Validación de semilla y del proceso de mantenimiento de agroecosistemaen los ejidos de California, Nueva Esperanza y Flores Magónlocalizadosen la zona de amortiguamiento de la reserva de la Biosfera la Sepultura; UNACH: Municipio de Villaflores, Mexico, 2010.

43. Purroy-Vázquez, R.; Ortega-Vargas, E.; Hernández-Santiago, Q.; Del Ángel-Piña, O.; Meza-Hernández, J.; Reyes-Santiago, B.; Nicolás-Vicente, F. Maize small-scale agroecosystems in the high Huasteca region of Veracruz: Economic-energetic efficiency and poverty. Rev. Agric. Soc. Desarro. 2019, 16, 105-121.

44. Funes, M.F.; Suarez, J.; Blanco, D.; Reyes, F.; Cepero, L.; Rivero, J.L.; Rodríguez, E.; Savran, V.; del Valle, Y.; Cala, M.; et al. Initial evaluation of integrated systems for food and energy production in Cuba. Pastos Forrajes 2011, 34, 445-462.

45. Funes, F.; Monzote, M.; Lantinga, E.A.; van Keulen, H. Conversion of specialised dairy farming systems into sustainable mixed farming systems in Cuba. Environ. Dev. Sustain. 2008, 11, 765-783. [CrossRef]

46. Pimentel, D. Handbook of Energy Utilization in Agriculture; CRC Press: Boca Raton, FL, USA, 1980.

47. Purroy-Vasquez, R.; Gallardo-Lopez, F.; Diaz-Rivera, P.; Ortega-Jimenez, E.; Lopez-Ortiz, S.; Torres-Hernandez, G. Energetic-economic flow as a tool to typify agroecosystems in the center of the state of Veracruz, Mexico. Ecosistemas Recur. Agropecu. 2016, 3, 91-101.

48. Stark, F.; Moulin, C.H.; Cangiano, C.; Vigne, M.; Vayssières, J.; González, G.E. Methodologies for evaluating farming systems. Part I. Generalities. Life cycle analysis (LCA) and ecological network analysis (ENA). PastosForrajes 2016, 39, 81-88.

49. Pimentel, D.; Pimentel, M. El uso de la energía en la agricultura, una visión general. LEISA Rev. Agroec. 2005, 21, 5-8.

50. Valdés, N.; Pérez, D.; Márquez, M.; Angarica, L.; Vargas, D. Funcionamiento y balance energetic en agroecosistemas diversos. Cultiv. Trop. 2009, 30, 36-42.

51. Schiere, J.B.; Ibrahim, M.N.M.; Van Keulen, H. The role of livestock for sustainability in mixed farming: Criteria and scenario studies under varying resource allocation. Agric. Ecosyst. Environ. 2002, 90, 139-153. [CrossRef]

52. Miranda, T.; Rey, M.; Hilda, M.; Julio, B.; Pedro, D. Economic valuation of environmental goods and services in two ecosystems of cattle use. Zootec. Trop. 2008, 26, 187-189.

53. Mandal, K.G.; Saha, K.P.; Ghost, K.M.; Hati, K.M.; Bandyopadhyay, K.K. Bioenergy and economic analysis of soybean-based crop production systems in central India. Biomas Energy. 2002, 23, 337-345. [CrossRef]

54. Purroy, V.R.; Gallardo, L.I.; Ortega, J.E.; Díaz, R.P.; López, O.S.; Torres, H.G. Energetic and economic efficiency, family welfare and productivity in tropical agroecosystems. Rev. Agric. Soc. Desarro. 2016, 13, 513-527.

55. Comisión Económica para América Latina y el Caribe (CEPAL). Informe Nacional de Monitoreo de la Eficiencia Energética de México; Organización de las Naciones Unidas: Ciudad de México, México, 2018; p. 195.

56. Instituto Para la Diversificación y Ahorro de Energía (IDAE). Ahorro y Eficiencia Energética en los Cultivos Energéticos y Agricultura; IDAE: Madrid, Spain, 2009; p. 35, ISBN 978-84-96680-43-2.

57. Chamorro, M.A.; Golik, I.S.; Bezus, R.; Pellegrini, E.A. Energetic analysis of four crop sequences in Buenos Aires Province, Argentina. Chil. J. Agric. Anim. Sci. (Ex Agro-Ciencia) 2015, 32, 20-31. [CrossRef]

58. Vences-Pérez, J.; Morales-Almaraz, E.; Martínez-Garcia, C.G.; Albarran-Portillo, B.; Garcia-Martínez, A. Energy efficiency and sustainability. The case of corn cultivation in dual purpose livestock systems in the state of Mexico. In Proceedings of the XLIV Reunion Cientifica de la Asociación Mexicana Para la Producción Animal y Seguridad Alimentaria, A.C. Clima y Ganaderia: Productividad Sustentable, Tuxtla Gutiérrez, Mexico, 6-8 September 2017; pp. 526-531.

(C) 2020 by the authors. Licensee MDPI, Basel, Switzerland. This article is an open access article distributed under the terms and conditions of the Creative Commons Attribution (CC BY) license (http://creativecommons.org/licenses/by/4.0/). 